\title{
Annette Grindsted*
}

\section{Negociación y el manejo de riesgos}

\begin{abstract}
The article defends the position that it is the construction of interpersonal relations that determines the zone of possible agreements in a negotiation rather than 'economic' considerations. It is assumed that negotiation is a communicative activity that implies risk and that to be able to initiate negotiations it is a precondition that a certain degree of trust has been established between the parties. Two different ways of conceptualizing trust are described, and two e-mail negotiations that give empirical support to these conceptualizations are analyzed. One reaches a dead-lock, the other does not.
\end{abstract}

\section{Introducción}

En cualquier libro sobre negociaciones comerciales se introducen modelos estratégicos muy arraigados en las "elecciones racionales" (rational choice) y la "teoría de los juegos" (game theory). Estos modelos prestan una gran atención al pensamiento económico intentando con ello asegurar que los negociadores pueden maximizar el valor propio, incluso a costa de la otra parte, si resulta necesario (Churchman 1995; Lewicki et al. 2007; Pruitt 1981). Desde un punto de vista teórica las “elecciones racionales" y la "teoría de los juegos" representan dos puntos de partida excelentes con los que podemos describir y entender el proceso de negociación. Al mismo tiempo creemos que ambos muestran también una serie de deficiencias. Una de ellas es la incapacidad de los mismos para explicar el comienzo de la negociación (Greenhalgh/ Chapman 1995; Vos/Wielers 2003). Al fin y al cabo la negociación es un proceso voluntario que puede encallar, incluso en la fase de 'prenegociación', si partimos de exploraciones iniciales que nos llevan a pensar que lo único que le interesa a la parte contraria es maximizar su

\footnotetext{
* Annette Grindsted

Dept. de Lingüística y de la Comunicación

Universidad Sur de Dinamarca

Campusvej 55

DK-5230 Odense $M$

agr@language.sdu.dk

Hermes - Journal of Language and Communication Studies no 41-2008
} 


\section{6}

propio beneficio. En este artículo intentamos esbozar otras perspectivas teóricas que las que nos pueden ofrecer la teoría de los juegos y de las elecciones racionales. Nos centramos en el estudio de los riesgos y la confianza, partiendo de la idea de que conceptualizaciones de confianza socio-afectivas pueden explicar, por lo menos en parte, por qué comienza o por qué no comienza una negociación seria, la forma en que ésta procede, el tipo de acuerdo alcanzado y la manera de llevarlo a la práctica.

\section{La negociación como actividad empresarial}

En la literatura empresarial sobre negociaciones, por regla general se basa, a nivel estratégico, en el famoso 'dual concerns model' (Lewicki et al. 2007). Este modelo invita al negociador a pensar en cómo puede maximizar el valor utilitario en una negociación con otra parte con la que tiene intereses conflictivos (Axelrod 1984). Además, se atribuye gran importancia a explicar el concepto del poder y sus repercusiones estratégicas y tácticas (Lewicky et al. 2007). Se mencionan confianza y riesgos sólo superficialmente. Nuestro punto de partida teórico es que si atribuiéramos igual de importancia a los conceptos de riesgo y confianza como fundamentos teóricos, probablemente seríamos capaces de explicar por qué las partes se deciden a buscar una solución negociada a algún problema.

\subsection{Negociación y riesgos}

Un problema más bien teórico que real es fijar el momento en que empieza una negociación. En la literatura relacionada con la investigación económica suele defenderse que una negociación se inicia en el momento en el que los negociadores se sientan a la mesa de negociación. Esta posición parece adecuada teniendo en cuenta que los datos empíricos que suelen usarse para analizar las negociaciones proceden de simulaciones llevadas a cabo en laboratorios en las que ya está prefijada la situación que desemboca en la negociación y predeterminados los asuntos a negociar. Algunos estudios con base empírica, sin embargo, han puesto de relieve que el momento en el que las partes deciden buscar una solución negociada a un problema concreto constituye un momento crítico en el proceso de negociación (Zartman/Bermann 1982; Habeeb 1988). 
La negociación se puede considerar como una respuesta a un conflicto o a uno o varios problemas. La verdad es, sin embargo, que no cualquier problema es negociable en cualquier momento. Como es bien sabido, es necesario por lo menos dos partes para poder negociar. Siguiendo una línea de argumentación más bien cognitiva y racional, solo podremos negociar cuando las dos partes realmente quieren negociar. Si una de las partes considera que no es posible llegar a una solución negociada al problema, éste o bien persistirá o bien se solucionará con el tiempo; o se solucionará gracias a procesos diferentes a la negociación, como pueden ser la vía judicial o el recurso de la fuerza (Ury et al. 1988; Greenhalgh/Chapmann 1995).

La negociación, por lo tanto, es un proceso voluntario que exige el cumplimiento de varias condiciones previas. La primera de ellas es que las partes entiendan que sus intereses comunes exceden a sus intereses en conflicto, al menos en lo que se refiere a ciertos problemas especifícos. Otra condición previa es que ambas partes crean que todas las partes implicadas realmente quieren llegar a un acuerdo, es decir, que piensan que llegar a un acuerdo es mejor que continuar con el conflicto (Ury et al. 2003; Greenhalgh/Chapmann 1995; Pruitt 1981, 1991).

No podemos forzar a la otra parte a aceptar un acuerdo. Para llegar a un acuerdo eficaz y duradero, éste tiene que ser aceptado por todas las partes para asegurar que cada una de ellas consigue, al menos, solucionar parte de sus intereses en conflicto.

Raras son las veces en las que las dos partes deciden explorar las posibilidades de negociar al mismo tiempo; es más habitual que una de las partes adopte la decisión inicial y a partir de ese momento intente influir sobre la otra parte. Esta situación es paradójica. Desde la perspectiva de la parte que propone negociar como método para resolver un problema, la decisión de negociar puede considerarse, por un lado, como un deseo de participar en cómo resolver un problema que todavía no ha sido reconocido por el no-negociador. Por otra parte, también se puede considerar como una señal de debilidad, puesto que la invitación a negociar implica, a la vez, la aceptación de 'ceder algo', o de cambiar posturas. En caso contrario no sería posible llegar a un acuerdo. Desde la perspectiva de la parte que ya no sabe si quiere negociar o no, le podría parecer ventajoso rechazar la invitación prima facie, ya que tal recha- 
zo podría señalar fuerza, en tanto que la aceptación se podría entender como una señal de debilidad (Zartmann/Biermann, 1982).

La interdependencia es el elemento clave que define la negociación. La mayor parte de las posiciones que debe tomar un negociador para satisfacer los objetivos que persigue no dependen exclusivamente de él mismo; influyen y se ven influidas por las decisiones que adopta su contrincante. Es por ello que parece probable que un negociador adopte de entrada el punto de partida que cree que va a defender la otra parte; es decir lo que piensa que piensa la otra parte; incluso puede incluir en sus consideraciones lo que piensa que piensa el otro que piensa uno mismo, y así sucesivamente (Thyssen, 2001). No es necesario indicar que cualquier cálculo que se haga se romperá si las dos personas basan sus estrategias en lo que piensan son las aspiraciones de la otra persona, y viceversa. Siempre hay, por consiguiente, cierto elemento de incertidumbre en cualquier negociación. El negociador debe correr riesgos. El negociador debe correr riesgos de forma que podemos decir que cuanto mayor sea el número de riesgos que está dispuesto a arrostrar, mayor será el nivel de confianza que muestra en la otra parte (Thyssen 2001, Knudsen 2001). Lo más seguro sería ser desconfiado, algo que, no obstante, le obligaría a pagar un precio muy alto, porque implicaría o bien reducir las necesidades a un mínimo, o bien maximizar los esfuerzos, por ejemplo, en el manejo de la información.

Todo lo que acabamos de señalar nos lleva a afirmar lo siguiente:

1) debe existir un cierto grado de confianza entre las partes a la hora de poder iniciar una negociación;

2) a partir del momento en que se acepta iniciar una negociación, también se acepta entablar una interacción arriesgada.

\subsection{La negociación desde la perspectiva comunicativa}

Desde la perspectiva de la comunicación la tensión se produce por la asimetría en la información entre las partes (Lewicky et al. 2007). La decisión de confiar (es decir , de revelar información crítica) se basa en un análisis de la credibilidad del otro y en un pronóstico del valor producido. Para poder manejarse bien en este campo de tensión el negociador tiene que cultivar tanto su imagen de firmeza como su imagen de fiabilidad (Pruitt 1982). Por un lado tiene que presentarse como una 
persona que se mantiene firme en sus decisiones, que despliega consistencia performativa y, además, que está poco inclinado a hacer concesiones. El dilema que sufre el negociador puede expresarse de la forma siguiente: “¿Cuánta información puedo transmitirle a mi contrincante? Si le doy demasiada información, puede beneficiarse de la misma en su propio provecho. Pero si le doy poca, la negociación puede estancarse y llegar a un punto muerto". Por otro lado, tiene que presentarse como una persona fiable, manifestando que su verdadera intención es buscar un acuerdo que puedan aceptar ambas partes (Pruitt 1981). Aquí el dilema del negociador sería: “¿hasta qué punto puedo confiar en la otra parte? Si tengo demasiada confianza, puede aprovecharse de mí en su propio provecho. Si confío poco, la negociación puede igualmente llegar a un punto muerto" (Lewicki et al. 2007).

Si tratamos de describir la problemática planteada como un juego de confianza, las estrategias pueden ir encaminadas a reducir el riesgo de perder valor utilitarista y a reducir la inseguridad en lo que se refiere a la credibilidad del otro. No dudamos en que tales estrategias son muy eficaces en lo que se refiere a reducir el riesgo de ser explotado. El problema es, sin embargo, que una vez implementadas, la otra parte las puede interpretar como falta de confianza lo que, a su vez, puede producir un impacto negativo en la negociación. Desde la perspectiva comunicativa, cualquier estrategia encaminada a reducir riesgos también transmite un mensaje interpersonal. Si A transmite el mensaje de que 'Quiero reducir el riesgo', el mensaje interpersonal puede ser 'No confío en tí'.

Cualquier mensaje transmite informaciones instrumentales o de contenido e informaciones interpersonales. Cualquier acto comunicativo afecta a las relaciones interpersonales. Simplemente no es posible comunicar sin definir la relación. En otras palabras, la confianza, entendida como cierta cualidad de la relación, se ve manifestada en y nutrida por la interacción. ¿Cómo entenderemos las relaciones entre los dos niveles del mensaje? Nuestra posición es que el nivel interactivo nos da instrucciones de cómo interpretar el nivel instrumental. Por consiguiente, la forma en que van desarrollándose las relaciones interpersonales determina cómo se desarrolla el proceso de negociación. Las cualidades de la relación determinan cómo las partes interpretan el comportamiento comunicativo de cada uno. Esto nos lleva a afirmar que son las relaciones interpersonales las que determinan la zona de posibles acuerdos. 


\section{Datos empíricos}

En este artículo llevamos a cabo un análisis de negociaciones realizadas por correo electrónico. En concreto, estudiaremos dos casos, uno caso coreano-danés, otro británico-danés (veánse anexos 1 y 2). En ambas negociaciones se discute el tema de la representación exclusiva de equipo electrónico. Desgraciadamente, la compañía que nos han dado el corpus que consiste de aproximadamente 200 mails en total, no nos han facilitado otros tipos de datos tales como resúmenes de reuniones, conversaciones telefónicas u otros tipos de interacción que han tenido las partes. Tampoco nos han ofrecido la posibilidad de asistir a estos tipos de interacción.

A pesar de que los datos son limitados, dan apoyo empírico a dos maneras totalmente distintas de conceptualizar la confianza como estrategia encaminada a reducir riesgos.

\section{Resultados y discusión}

\subsection{Negociación y tecnología informática}

Todavía no se sabe mucho de cómo el uso de tecnología informática afecta al proceso de negociar y sus resultados. Proyectos de investigación experimental en que el correo electrónico fue el único medio utilizado parecen indicar que si las partes no se conocen de antemano y, por consiguiente, tampoco son capaces de compartir identidades, tienen dificultades en librarse de cierta ansiedad inicial. Por eso, están poco dispuestos a intercambiar informaciones que, como ya sabemos, es una condición previa para poder llegar a acuerdos duraderos. Sin embargo, negociaciones llevadas a cabo por correo electrónico no impiden la construcción de relaciones interpersonales de confianza si las partes también toman parte en otras formas de interactuar, tales como reuniones cara a cara o conversaciones telefónicas (Nadler/Shestowsky 2006; Wu/Laws 2003). Como hemos señalada en la sección 3, sabemos a ciencia cierta que las partes se conocen de tales actividades interactivas.

\subsection{El caso coreano/danés}

La empresa coreana (ver anexo 1) incia el contacto con la empresa danesa con una visita del director de ventas internacionales que tiene como 
objetivo introducir los productos coreanos (Mail 1). El director danés se muestra interesado (mail 2) y se inicia la negociación sobre un posible acuerdo de ventas en torno a tres puntos principales: 1) territorio de ventas, 2) horizonte temporal, y 3) garantía en las ventas (ver Anexo 1). La Figura 1 muestra la zona de posibles acuerdos:

\begin{tabular}{ll}
$\begin{array}{l}\text { Coreanos } \\
\text { Territorio de ventas }\end{array}$ & $\begin{array}{l}\text { Daneses } \\
\text { Territorio de ventas }\end{array}$ \\
\hline $\begin{array}{l}\text { Dinamarca, Suecia, Noruega, } \\
\text { Finlandia, Islandia }\end{array}$ & $\begin{array}{l}\text { Dinamarca, Suecia, Noruega, } \\
\text { Finlandia, Islandia, Países Bálticos }\end{array}$ \\
$\underline{\text { Tiempo }}$ & $\underline{\text { Tiempo }}$ \\
Inmediatamente & En unos meses \\
$\underline{\text { Garantía de ventas }}$ & $\underline{\text { Garantía de ventas }}$ \\
\hline 50.000 al mes & Estimado, sin compromiso
\end{tabular}

Figura 1. Zona de posibles acuerdos

El interés de los coreanos es minimizar el territorio de ventas y el horizonte temporal, y maximizar la garantía de ventas.

Ejemplo 1:

Posiciones coreanas:

3. Exclusivity

Scandinavian countries will do, but for Baltic countries, we have already our own business partners there, so please excuse me asking you to wait a bit more until your business is proven to be good. (Mail 6)

But in order for me to draw the document for Exclusivity, can you assure a certain amount monthly? I would suggest $\$ 50,000$ per month. Can you guarantee this amount? (Mail 15)

Then could you kindly tell me your suggestion on how much you can assure for the starting year since you are asking for exclusivity for the whole northern European market. (Mail 16)

Por su parte el interés de los daneses es maximizar el territorio de ventas y el horizonte temporal, y minimizar la garantía de ventas.

Ejemplo 2:

Posiciones danesas: 
3) Proposal for a Distribution agreement for Scandinavia and if possible including the Baltic Countries Estonia, Latvia and Lithuania. (Mail 5)

I do not know the quantity the first year.

It will take some months to build up the market, I think that we will reach a turnover in December next year of US\$ 30.000, increasing gradually op to US\$ 50.000 mid 2007.

The marketing can start in January 2006.

Turnover in November/December 2005 could be US \$ 7.000,00. (Mail

17)

Para llevar a cabo sus intereses los coreanos utilizan una táctica competitiva, que consiste en informar que están negociando con otra gran empresa sobre el territorio que también les interesa a los daneses.

\section{Ejemplo 3:}

As a positive negotiation with a big company in your area is now progressing favorably, I believe your quick action would help me a lot.

(Mail 12)

Los daneses, por otra parte, prefieren una táctica cooperativa al indicar que ya han empezado la traducción a otras lenguas escandinavas del material que debe acompañar a los productos que desean vender.

Ejemplo 4:

2) Amtronic will translate the language from english into: a) Danish (can also be used for Norway), b) Swedish, c) Finish and d) Lithuanian, we wuld prefere to implement the language into the software ourselvs will that be possible??? (Mail 5)

En un momento determinado los coreanos proponen que la empresa danesa venda los productos sin exlusividad.

Ejemplo 5:

1. You can start selling our DVR without any regulation for the time being. (Mail 20)

Los daneses sospechan que los coreanos están negociando al mismo tiempo una representación exclusiva de los mismos productos con otras empresas sobre los mismos productos en el mismo territorio y suspenden las negociaciones. 
Ejemplo 6:

I have just received the E-mail below from your company, and I take it

for granted that other Danish Companies has got equivalent E-mails.

Does that mean that you have given up dealing with us??

Have you. (Mail 21)

\subsection{El caso británico-danés}

El segundo de los casos (ver anexo 2) que analizamos se refiere a una negociación entre una empresa británica y una danesa, que, como vemos en el ejemplo (7) ya han tenido una conversación telefónica anterior:

Ejemplo 7:

Good Morning Per,

It was great to talk with you yesterday, although I am disappointed that under the basis of a written exclusivity arrangement, it would appear that we cannot work together? (Mail 1)

As mentioned at our meeting and on the telephone yesterday, while we have relationships and partnerships with companies throughout the world, none of these are administered on the basis of a signed exclusivity agreement. (Mail 1)

Based on our conversation yesterday, we may have already 'missed the boat'. This would be very disappointing to me. If you decide to work with AR because they can provide a written exclusivity agreement, then so be it. However, it is what happens on a day to day basis that is important, not what is written on a document sitting in a drawer. (Mail 1)

Whatever you ultimately decide, it was great to meet with you and Kim a week or so ago and thanks for considering PIPS Technology. (Mail 1)

Vemos en el ejemplo que ya han discutido la forma y el contenido de un posible acuerdo sobre representación exclusiva. La posición de las dos partes es clara: los daneses quieren un acuerdo firmado, mientras que los ingleses no quieren nada por escrito. La Figura 2 ilustra la zona de posibles acuerdos. 


$\begin{array}{ll}\longleftrightarrow \text { Ingleses } & \text { Daneses } \\ \underline{\text { Forma del acuerdo }} & \underline{\text { Forma del acuerdo }} \\ \text { Ningún acuerdo firmado } & \text { Acuerdo escrito y firmado }\end{array}$

Figura 2. Zona de posibles acuerdos

En su estrategia persuasiva, los ingleses argumentan en contra de acuerdos escritos de representación exclusiva:

Ejemplo 8:

However, this does not mean that we do not work with and protect companies as if a signed exclusivity agreement was in place (Mail 1)

I appreciate that 'words are cheap'. However, regardless of whether a relationship is conducted on the basis of a signed exclusivity agreement or not, we can only screw each other once. In my experience, signed agreements stay in the drawer until one or other of the parties has an issue. Whether this agreement is in place or not, the key element is trust. (Mail 1)

Al mismo tiempo se refieren a una serie de actos de confianza, como vemos en el ejemplo (9) en el que se observa la referencia a su experiencia con otros agentes, la protección que les dispensan, a los proyectos en desarrollo, a las ventas crecientes, etc.). Incluso afirman que el elemento clave es la confianza.

Ejemplo 9:

However, this does not mean that we do not work with and protect companies as if a signed exclusivity agreement was in place. (Mail 1)

2. We mutually established a close working relationship with key personnel (Mail 1)

3. As turnover has grown, the mutual relationship has flourished (Mail 1)

Whether this agreement is in place or not, the key element is trust. (Mail 1)

However, through action and deed, we work closely together to close opportunities as they arise, without any conflict. (Mail 1) 
Vemos que el representante danés se deja convencer y unas horas más tarde declara "we are in business":

Ejemplo 10:

It appears to me that the description below is more or less equivalent to exclusivity! (Mail 2)

If we can be sure that our business relation will be in accordance with your description I see no problems for us to start. (Mail 2)

Thanks, we are in business; I am leaving for Norway in a few minutes and will present your products as discussed. (Mail 4)

\subsection{La confianza y sus conceptualizaciones}

Los casos que acabamos de comentar ilustran que la confianza implica el establecimiento de una relación de interdependencia entre dos personas gracias a la cual se formulan, consciente- o inconscientemente, hipótesis sobre actos futuros de la otra persona. Depositar confianza en otra persona supone que se acepta correr un riesgo con el fin de reducir la inseguridad. Si se muestra confianza, se corre el riesgo de sufrir algún tipo de abuso o explotación. Esta aceptación de vulnerabilidad se debe, precisamente, a que no se espera que la otra parte se aproveche de la situación para su propio beneficio (Sztompka 1999; Thyssen 2001; Nootebom 2003).

Se puede conceptualizar la confianza en, al menos, dos formas distintas: una cognitiva y racional; la otra afectiva y social. En el primero de los casos se puede minimizar el riesgo si se puede predecir el comportamiento del otro. Es decir, cuánto mayor es nuestro nivel de seguridad, menor será el nivel de confianza que se necesita, ya que la confianza cognitiva se basa en un cálculo racional sobre la posibilidad de que la otra parte satisfaga nuestras esperanzas tomando como punto de partida un cierto esceptisismo o interés propio. En nuestros datos, el caso coreano-danés, mails 13-20, reflejan esta forma de pensar.

Si usamos la teoría de juegos como marco de referencia para entender la confianza, partimos de la presuposición implícita de que cuanto mayor sea la aportación de una parte, tanto mayor será la necesidad de confiar en la otra. La opción de confiar es racional sólo en el caso de que el valor que se espera generar sea superior al aportado. De esta forma la confianza se considera equivalente al cálculo de probabilidades, y pare- 
ce coincidir con la previsión/predicción. Previsión y confianza, sin embargo, son dos fenómenos completamente distintos (Williamson 1993). Si el cálculo de probabilidades lleva a seguridad completa se elimina la necesidad de confiar o correr riesgos.

Lo que acabamos de señalar hace que la postura tomada aquí sea que esta conceptualización puramente instrumental y racional sólo es capaz de explicar una pequeña parte de lo que quiere decir "confianza”. Si no fuera así, el término sería engañoso. La confianza también connota algo positivo. No hablamos de confianza si creemos que otra persona tiene malas intenciones. Una persona cuyos actos están motivados únicamente por el interés propio es previsible, pero no es digna de merecer nuestra confianza. La confianza también es un fenómeno social que va desarrollándose gracias a la interacción entre dos personas. Es un fenómeno que también tiene que ver con los sentimientos y los vínculos sociales. Esta confianza afectiva afecta la identidad social. Afecta el respeto y aprecio mutuo, y la creencia en que ambas aspiran a buscar el beneficio mutuo. Afecta, además, la dimensión ética. En resumen, esta conceptualización está basada en nuestra predilección por mantener buenas relaciones interpersonales, las cuales podrían tener suficiente fuerza para resistir la presión externa. Se confía en la buena voluntad de otras personas, en que importan la identificación social y los sentimientos éticos. En nuestros datos, el caso británico-danés, refleja bien esta conceptualización, en particular mail 1.

Creo que ambas conceptualizaciones son relevantes, incluso entre negociadores. Al depositar nuestra confianza en otra persona, entra en juego un elemento cognitivo y uno afectivo. Sin el elemento afectivo, la confianza quedaría reducida a fríos cálculos. Igualmente, sin el elemento racional, se vería reducida a confianza ciega. Es por ello que cualquier negociación debe basarse en el establecimiento de una confianza afectiva y racional. Gracias a ella los negociadores verían reducidos los riesgos que corren en cualquier proceso negociador. Para ello proponemos un modelo de negociación que tenga en cuenta la interrelación de los diferentes niveles informativos con las dos conceptualizaciones de “confianza” que acabamos de señalar (Figura 3). 
$\begin{array}{ll}\text { Niveles informativos } & \text { Tipos de confianza } \\ \text { El instrumental } & \text { El cognitivo y racional } \\ \text { El interpersonal } & \text { El socio-afectivo }\end{array}$

Figura 3. Interrelación del nivel informativo y los tipos de confianza

Con este modelo podemos afirmar que en el primero de los dos casos analizados la negociación falla al primar los riesgos económicos y utilitaristas (es decir, la confianza del tipo “cognitivo") quedando relegada a un segundo plano la relación interpersonal que solo se manifiesta al final cuando el coreano acusa al negociador danés de no ser justo.

Ejemplo 11:

But, please understand that it's not fair that we have to ensure your maket without your sales guarantee toward us (Mail 18).

En el segundo de los casos, sin embargo, la negociación es más prometedora porque se tienen en cuenta los dos niveles. El negociador británico atribuye valores positivos a la relación (confianza socio-afectiva) y afirma que son ellos lo que han determinado los buenos resultados económicos obtenidos con otros socios.

Ejemplo 12:

\begin{abstract}
I appreciate that 'words are cheap'. However, regardless of whether a relationship is conducted on the basis of a signed exclusivity agreement or not, we can only screw each other once. In my experience, signed agreements stay in the drawer until one or other of the parties has an issue. Whether this agreement is in place or not, the key element is trust. Neither company can grow without the unequivocal input and support of both companies. As well as the above examples, we have partnerships with people in Spain and Poland, where no written exclusivity exists, yet there is a platform of total trust, resulting in maximised business growth. (Caso británico-danés, Mail 1)
\end{abstract}

\title{
5. Conclusión
}

Hemos afirmado que una condición previa para poder negociar es que se haya establecido cierto grado de confianza entre las partes dado que en la negociación siempre se corren riesgos. Es indiscutible que el paradigma racional y económico es central en la negociación. Sin embargo, si reducimos la comprensión del proceso de negociar únicamente a pensamientos racionales y económicos, excluyendo la dimensión rela- 
cional, no podemos explicar cómo se inicia una negociación, ni cómo se llega a un acuerdo. Según nuestra línea de pensamiento, es precisamente la cualidad de la relación la que determina la zona de posibles acuerdos.

\section{ANEXO 1}

\section{CASO COREANO-DANES}

\section{MAIL 1}

Fra: James Kang

Sendt: 31. maj 2005 11:31

Til: Per Jensen

Emne: visiting Denmark

Prioritet: $\mathrm{H} \odot{ }^{\mathrm{a} j}$

Dear Mr. Per Jensen,

It is my great pleasure and honor to have a chance to write this.

First, I am James Kang, regional sales manager of Tibet system, one of leading Korean PC-based DVR manufacturers.

Honestly, Mr.Paul You (from Apromedia, the camera manufacturer you are working with) introduced me your esteemed company and I really don't want to lose this chance in order to show you our DVR products.

As I am staying in Denmark from 27th June to 5th July, if you could spare me only some of your convenient time, I really would like to do some demonstration with our DVR unit for you.

I am well understanding how much you are busy with your own work everyday, but at the same time I guess you must be well aware of the fact that

$\mathrm{i}^{\circ}$ there ${ }^{-}{ }^{-}$s none the best forever, but there is a better one certainly. $\mathrm{i}^{ \pm}$

Herewith, $\mathrm{I}_{\mathrm{i}}{ }^{-} \mathrm{m}$ attaching a PDF file showing all about our company and products.

Please review my proposal with this file, and let me hear your positive answer that will be my biggest pleasure at the moment.

Thank you so much for your precious time.

$\mathrm{I}_{\mathrm{i}}{ }^{-}$ll call you soon. 
Have a nice day!

Kindest

James Kang/Overseas sales Dep. regards,

\section{MAIL 2}

From: Per Jensen

To: James Kang

Sent: Wednesday, June 01, 2005 9:00 PM

Subject: SV: visiting Denmark

Dear Mr. James Kang,

You are welcome to visit us in the period mentioned.

Best regards

Per Jensen

MAIL 3

Fra: James Kang

Sendt: 1. juni 2005 14:08

Til: Per Jensen

Emne: Re: visiting Denmark

Dear Mr.Per Jensen,

It is my biggest happiness to hear your warm words.

Then, could you please tell me the date and time that is the best for you, because I really don't want to disturb your business.

Thank you so much again.

Best regards,

James Kang

\section{MAIL 4}

Fra: James Kang

Sendt: 19. juni 2005 19:03

Til: Per Jensen

Emne: visiting your office 


\section{Prioritet: Høj}

Dear Mr. Per Jensen,

Further to my e-mail for my visit to your company, please let me see you on 27th June.

Also, please let me know your convenient time so I can arrange proper schedule.

Thank you so much for your kind welcome again.

Best regards,

James Kang / regional sales manager

\section{MAIL 5}

From : Per Jensen

To : James Kang

Cc :

Receive Date : Wed, 10 Aug 2005 18:12:1 +0900 (KST), Wed, 10 Aug 2005 11:06:41 $+0200$

Subject : MagicRadar

Dear Mr. James Kang,

We have been testing the DVR Boards from you during the last weeks, and apart from the printout resolution, which take place with resolution $640 \times 480$ and not the announced $720 \times 576$, the system is running fine.

Our Kim Karlsen has been in contact with you regarding the resolution and I understand that the printout resolution will be upgraded??

We are now ready to proceed with our cooperation and we ask you to confirm the following procedures:

1) Amtronic must be able to change the GUI in order to implement the Amtronic logo and our customers logo.

2) Amtronic will translate the language from english into: a) Danish ( can also be used for Norway), b) Swedish, c) Finish and d) Lithuainian, we would prefere to implement the language into the software ourselves will that be possible???

3) Proposal for a Distribution agreement for Scandinavia and if possible including the Baltic Countries Estonia, Latvia and Lithuania. 
After your confirmation of above and our distributorship for Scandinavia (Denmark, Norway, Sweden and Finland) we will proceed with 1) and 2) and launch the Magic Radar products on our market about September 15th o5.

Best Regards

Per Jensen

\section{MAIL 6}

Fra: James Kang

Sendt: 10. august 2005 21:11

Til: Per Jensen

Emne: Reply:MagicRadar

Dear Mr. Per Jensen,

Thank you so much for your kind information.

As I informed Mr.Kim Karlsen yesterday, I'm now in Ireland so please let me give you answers on technical issues when I go back to Korea.

However, for your business requests,

1. logo changes

As promised in our meeting in Copenhagen, yes it is acceptable. But for GUI, could you give some ideas which parts of our current MagicRadar GUI would you like to change?

2. language translation

Yes, acceptable. I'll send you strings to be translated in each Languages.

3. Exclusivity

Scandinavian countries will do, but for Baltic countries, we have already had our own business partners there, so please excuse me asking you to wait a bit more until your business is proven to be good.

Again to say, I appreciate your kind cooperation regarding this matter. I really wish we can build long term‘s business relationship upon this opportunity.

For any question or request, please feel free to tell me.

Best regards,

James Kang 


\section{MAIL 7}

Fra: James Kang

Sendt: 26. august 2005 09:15

Til: Per Jensen

\section{Emne: PRICELIST}

Dear Mr. Per Jensen,

Hope all is well with you.

Herewith, I'm attaching a Pricelist of our DVR boards.

Please check it and advise me if those prices are accepatable.

Also, in the file, I quote you for our Linux DVR boards.

If you are interested in our Linux DVR, please feel free to tell me.

Our Linux DVR has almost same functions with Windows DVR, but unfortunately Linux doesn't have Live models such as LS16 or LD16.

We provide our own Linux OS and you only have to pay extra \$10 + each Windows model.

This $10 \$$ is for our own Linux OS, so you can save some money that you are spending for MS Windows OS.

For more information, please let me know.

Thank you and best regards,

James Kang/Overseas sales Dep.

\section{MAIL 8}

Fra: James Kang

Sendt: 30. august 2005 11:53

Til: Kim Olsen; Per Jensen

Emne: new features into 4.2.0.0 version

Dear Mr.Per Jensen and Mr.Kim Olsen,

Please see the file attached showing new features into our new version 4.2.0.0

This version will be released very soon and I hope you like it.

For any question, please feel free to ask me. 
Best regards,

James Kang/Overseas sales Dep.

\section{MAIL 9}

From: Per Jensen

To: James Kang

Cc: Kim Olsen

Sent: Wednesday, August 31, 2005 8:59 PM

Subject: SV: new features into 4.2.0.0 version

Dear James,

Thanks, it looks very god.

I expect that we can start our cooperation in the nearest future.

Kim will keep in touch with you.

Best Regards

Per

\section{MAIL 10}

Fra: James Kang

Sendt: 6. september 2005 11:45

Til: Per Jensen

Emne: Re: new features into 4.2.0.0 version

Dear Mr.Per Jensen

So nice talking with you on the line.

I noted well that your translated will be done by this weekend.

I'll be waiting, then.

Also, is there anything I can help you, please don't hesitate to contact me.

Have a nice day!

Best regards,

James 
MAIL 11

Fra: James Kang

Sendt: 14. september 2005 12:40

Til: Kim Olsen; Per Jensen

Emne: MagicRadar DVR develoment schdule

Again, I appreciate your kind cooperation for everything.

By the way, below is our developing schedule that you will have in the future, so please refer to these information for your sales.

1. New DVR manager ( MDVR )

New DVR manager which can monitor upto 200 DVRs is coming out next week.

Users can watch 64channels on a screen.

I' $m$ attaching an image for the MDVR.

Don't forget that all our software is free served.

2. PDA viewer

Now users can observe MagicRadar DVR on PDA from October.

3. 16CH with 400FPS/400FPS

Certainly come out by the end of October in supreme quality and good price

4. Stand-Alone DVR

For the beginning, 4CH with 100fps/100fps in triplex StandAlone will come out by the end of this year.

Our target price is around USD300 per unit.

Right after that, $8 \mathrm{CH}$ and $16 \mathrm{CH}$ will come out in a row.

For any question, please let me know.

Thank you so much again for your time and have a nice day!

Best regards,

James Kang

MAIL 12

Fra: James Kang

Sendt: 16. november 2005 05:44

Til: Per Jensen 
Emne: from MagicRadar

Dear Mr.Per Jensen,

I hope everything is well with you.

I'm now back to the office from Russia.

I wish it was a successful trip also for you.

However, as discussed in our office and at the exhibition, I'm now waiting for your final decision.

For Russian market, I'm going to privilege my current Russian partner to take whole Russian market for the time being.

As a positive negotiation with a big company in your area is now progressing favorably, I believe your quick action would help me a lot.

For any question, please let me know.

Looking forward to hearing from you.

Best regards,

James Kang

\section{MAIL 13}

From: Per Jensen

Sent: Thursday, November 17, 2005 6:17 PM

To: James Kang

Subject: Draft fo Distributorship Agreement. SV: from MagicRadar

Dear James,

ThankÆ¥s all is well.

Please send a draft for Exclusive Distributorship Agreement in our territories, Denmark, Sweden, Norway, Finland and Island.

Best Regards

Per Jensen

MAIL 14

To: James Kang

Sent: Thursday, November 17, 2005 9:04 PM 
From: Per Jensen

Subject: SV: Draft fo Distributorship Agreement. SV: from MagicRadar

Dear James,

US\$ 50.000 / month is equivalent to app. 250 DVR Boards monthly which should be possible in year 2 .

It will take some time to build up the market and make the product known.

I suggest that the quantity should be set to US\$ 50.000 / month after 18 months.

Best Regards

Per

MAIL 15

Fra: James Kang

Sendt: 17. november 2005 12:53

Til: Per Jensen

Emne: Re: Draft fo Distributorship Agreement. SV: from MagicRadar

Dear Mr. Per Jensen,

No problem.

But in order for me to draw the document for Exclusivity, can you assure a certain amount monthly?

I would suggest $\$ 50,000$ per month. Can you guarantee this amount?

Best regards,

James

\section{MAIL 16}

Fra: James Kang

Sendt: 18. november 2005 12:39

Til: Per Jensen

Emne: Re: Draft fo Distributorship Agreement. SV: from MagicRadar

Dear Mr. Jensen,

I well understand your stand.

Then could you kindly tell me your suggestion on how much you can assure for the starting year since you are asking for exclusivity for the whole northern European market. 
Looking forward to hearing from you soon,

Best regards,

James

MAIL 17

To: James Kang

Sent: Friday, November 18, 2005 11:04 PM

From: Per Jensen

Subject: SV: Draft fo Distributorship Agreement. SV: from MagicRadar

Dear James,

I do not know the quantity the first year.

It will take some months to build up the market, I think that we will reach a turnover in December next year of US\$ 30.000, increasing gradually op to US\$ 50.000 mid 2007.

The marketing can start in January 2006.

Turnover in November/December 2005, could be US \$ 7.000,00.

We would need 20 PCS CS16 ASAP after the signing of the contract, how soon can you ship these?

Best Regards

Per

\section{MAIL 18}

Fra: James Kang

Sendt: 21. november 2005 10:36

Til: Per Jensen

Emne: Re: Draft fo Distributorship Agreement. SV: from MagicRadar

Dear Mr. Jensen,

Thanks a lot for your market forecast.

But, please understand that it's not fair that we have to ensure your maket without your sales guarantee toward us.

From our point of view, Northern Europena market is not that small one, so it is hard for me to agree your suggestion.

But, I have an idea. 
You can start selling our DVR without any regulation between Amtronic and Tibet System.

I'll not ask you to ensure the certain amount, so please you do not also ask me the contract.

And later, if both of us can agree to take further step, it would be better for us to keep the contract.

However, so far, you didn`t show me anything, so it would be so appreciated if you could show me now.

For the shipment, we are always ready to ship as soon as we check money transfer.

Best regards,

James

MAIL 19

To: James Kang

Sent: Monday, November 21, 2005 10:16 PM

From: Per Jensen

Subject: SV: Draft fo Distributorship Agreement. SV: from MagicRadar

Dear Kang,

We are not interested in selling your products in Scandinavia without exclusivity.

We could make a compromise starting with exclusivity in Denmark, if this is interesting for you we can start.

Best Regards

Per Jensen

MAIL 20

Fra: James Kang

Sendt: 25. november 2005 09:39

Til: Per Jensen

Emne: Re: Draft fo Distributorship Agreement. SV: from MagicRadar

Hello Mr. Jensen,

I'm so sorry for I couldn't reply you earlier.

However, I think there can be 2 options. 
1. You can start selling our DVR without any regulation for the time being. Then, later if both of us are satisfied with each's business policy and so on, we can come to make an agreement for the exclusivity contract.

This will allow you to have time to test our products in your market, while we can also judge your sales capablility.

I will suggest that we make the agreement with exclusivity limited for one year based on my earlier budget. After 8 months the Agreement is prolonged for another year should both parties be satisfied.

2. If you want the exclusivity for Denmark from the start,

I would like you to ensure \$20,000 monthly buying amount from next January.

This will not be possible, as the market campaign for TIBET Boards will be launched in January 2006.

Above are my suggestion, but it would be so appreciated if you could give me a better idea.

Looking forward to hearing from you soon,

Best regards,

James

\section{MAIL 21}

From: Per Jensen

Sent: Tuesday, December 06, 2005 9:34 PM

To: HG Kang

Subject: SV: A letter from CNB

Importance: High

Dear Kang,

I have just received the E-mail below from your company, and I take it for granted that other Danish Companies has got equivalent E-mails.

Does that mean that you have given up dealing with us??

Have you

Best regards

Per Jensen 


\section{ANEXO 2 \\ CASO BRITANICO-DANES}

Fra: Kevin Jones

Sendt: 13. december 2005 10:49

Til: ,Per Jensen`

Emne: PIPS TECHNOLOGY

Good Morning Per,

It was great to talk with you yesterday, although I am disappointed that under the basis of a written exclusivity arrangement, it would appear that we cannot work together?

As mentioned at our meeting and on the telephone yesterday, while we have relationships and partnerships with companies throughout the world, none of these are administered on the basis of a signed exclusivity agreement. However, this does not mean that we do not work with and protect companies as if a signed exclusivity agreement was in place. For example, our two most successful international partners are in Australia and Holland respectively. We do not have a signed exclusivity agreement in place with either of these companies. Yet each of these companies has been able to develop annual turnover, in their local territory, in excess of $£ 300,000$, within the last 3 years. How have they been able to do this?

1. Both of the above companies have a complimentary product range to the PIPS product portfolio. This means that they can maximise overall potential per tender / project.

2. We mutually established a close working relationship with key personnel. As such, if a request arises out of their territory, it is bounced straight to the respective company. Therefore, if we receive an invitation to quote or tender from each of these territories or indeed, from another territory but for supply into each of these territories, then we communicate this to them. This gives them total ownership of their territory and they are free to grow business on behalf of PIPS, without the fear of us establishing competition against them.

3. As turnover has grown, the mutual relationship has flourished and each of these companies has grabbed more of our attention. This has meant that we have spent an increasing amount of time and resource on developing products more closely tailored to their country specific needs.

I appreciate that 'words are cheap'. However, regardless of whether a relationship is conducted on the basis of a signed exclusivity agreement or not, we can only screw each other once. In my experience, signed agreements stay in the drawer until one or other of the parties has an issue. Whether this agreement is in place or not, the key element is trust. Neither company can grow without the unequivocal input and support of both companies. As well as the above examples, we have partnerships with people in Spain and Poland, where no written exclusivity exists, yet there is a platform of total trust, re- 
sulting in maximised business growth. No single company can cover all of our target markets in any given territory. However, through action and deed, we work closely together to close opportunities as they arise, without any conflict.

As you are aware, I am very keen to work with Amtronic. I believe that you have a strong platform from which to increase penetration of PIPS License Plate Recognition into your core territories. I also believe that we can work together on the basis of mutual cooperation and trust. It is my objective to grow business in your territories. With little business being generated from your territories, it would be madness for me to establish a position where you are competing against yourself. I would very much like to give our relationship a shot. As business grows and our relationship becomes stronger, I am sure that you would not be disappointed with the support and protection that you would receive.

Based on our conversation yesterday, we may have already 'missed the boat'. This would be very disappointing to me. If you decide to work with AR because they can provide a written exclusivity agreement, then so be it. However, it is what happens on a day to day basis that is important, not what is written on a document sitting in a drawer.

Whatever you ultimately decide, it was great to meet with you and Kim a week or so ago and thanks for considering PIPS Technology.

Very Best Regards,

Kevin

Kevin Jones,

European Sales Manager

MAIL 2

From: Per Jensen

Sent: 13 December 2005 12:51

To: Kevin Jones

Subject: SV: PIPS TECHNOLOGY

Dear Kevin,

Thanks. It appears to me that the description below is more or less equivalent to exclusivity!

If we can be sure that our business relation will be in accordance with your description I see no problems for us to start.

I take it for granted that we/you can embed our name in the software as you mentioned during your visit to our office. 


\section{2}

I look forward to hearing from you.

Best Regards

Per Jensen

\section{MAIL 3}

Fra: Kevin Jones

Sendt: 13. december 2005 14:31

Til: ,Per Jensen‘

Emne: RE: PIPS TECHNOLOGY

Prioritet: Høj

Hi Per,

Thanks for your reply, as I do appreciate that you are headed for Norway very shortly. I guess that in my mail, I was trying to illustrate how we have successfully worked with companies in the past and yes, this does more or less equate to exclusivity. It really is a two way street and it would delight me to work with you, in your respective territories, so that we can really optimise the potential that I am convinced exists. You therefore have my word that business will be conducted as outlined below.

Your logo CAN be embedded on the AutoPlate software. This is very easy for us to do.

I really appreciate your reply and faith in PIPS Technology and I am very much looking forward to working with you. I wish you a successful and safe trip to Norway and will call you later in the week.

Very Best Regards,

Kevin

\section{MAIL 4}

From: Per Jensen

Sent: 13 December 2005 13:24

To: Kevin Jones

Subject: SV: PIPS TECHNOLOGY

Dear Kevin,

Thanks, we are in business; I am leaving for Norway in a few minutes and will present your products as discussed.

Best Regards

Per Jensen 


\section{MAIL 5}

Fra: Kevin Jones

Sendt: 13. december 2005 14:46

Til: 'Per Jensen'

Emne: RE: PIPS TECHNOLOGY

Hi Per,

That's great news and I wish you a safe trip.

If you need any help in the meantime, then please let me know...

$\mathrm{BR}$,

Kevin

\section{Bibliografia}

Albin, Cecilia 1993: The Role of Fairness in Negotiation. En Negotiation Journal 9, (3), 223-245

Axelrod, Robert 1984: The Evolution of Cooperation. New York: Basic Books.

Bordum, Anders 2001: Tillid er godt! - Om tillidsbegrebets værdiladning. En Bordum, Anders/Wenneberg, Søren Barlebo (eds.), Det handler om Tillid. Copenhague: Samfundslitteratur, 57-68.

Churchman, David 1995: Negotiation. Process, Tactics. Theory. 2. ed. University Press of America.

Greenhalgh, Leonard/Chapman, Deborah I. 1995: Joint Decision Making - The Inseparability of Relationships and Negotiation. En Kramer, Roderick M./Messick, David M. (eds.), Negotiation as a Social Process. Sage Publications, 166-186.

Knudsen, Morten 2001: Krop og suverænitet - om to måder at skabe tillid på. En Bordum, Anders/Wenneberg, Søren Barlebo (eds.), Det handler om Tillid. Copenhague: Samfundslitteratur, 15-23.

Lewicki, Roy J./Bunker, B. B. 1995: Trust in relationships: A model of trust development and decline. En Bunker/Rubin (eds.), Conflict, Cooperation and Justice. San Francisco: Jossey-Bass, 166-186.

Lewicki, Roy J./Saunders, David M./Barry, Bruce/Minton, John W. 2004: Essentials of negotiation. 3. ed. McGrawHill.

Martin, D. et al. 2003: International Negotiations: An Entirely Different Animal. En Lewicki Roy J. et al. (eds.), Negotiation - Readings, Exercises and Cases. McGrawHill, 340-354. 
Nadler, Janice/Shestowsky, Donna 2006: Negotiation, Information Technology, and the Problem of the Faceless Other. En Thompson, Leigh L. (ed.), Negotiation Theory and Research. New York: Psychology Press.

Neale, Margaret A./Bazerman, Max H. 1991: Cognition and Rationality in Negotiation. New York: Free Press.

Nooteboom, Bart 2003: The trust process. En Nooteboom, Bart/Six, Frédérique (eds.), The Trust Process in Organizations. Edward Elgar Publishing, 16-36.

Pruitt, Dean G. 1981: Negotiation Behavior. New York: Academic Press.

Pruitt, Dean G. 1991: Strategic Choice in Negotiation. En Breslin, J. William/Rubin Jeffrey Z. (eds.), Negotiation Theory and Practice. The Programme on Negotiation at Harvard Law School. Cambridge, Massachusets, 27-46.

Pruitt, Dean G./Carnevale, Peter J. 1993: Negotiation in Social Conflict. Buckingham: Open University Press.

Pruitt, Dean G./Smith, D. Leasel 1981: Impression Management in Bargaining: Images of Firmness and Trustworthiness. En Tedeschi, J.T. (ed.), Impression management theory and social psychological theory. New York: Academic Press, 247-267.

Savage, Grant T./Blair, John D./Sorenson, Ritch L. 2003: Consider both Relationhips and Substance When Negotiating Strategically. En Lewicki, Roy J. et al. (eds.), Negotiation - Readings, Exercises and Cases. 4. ed. McGrawHill, 23-40.

Shapiro, Debora L./Sheppard, Blair H./Cheraskin, Lisa 1992: Business on a Handshake. En Negotiation Journal 8 (4), 365-379.

Sztompka, Piotr 1999: Trust. A Sociological Theory. Cambridge University Press.

Thyssen, Ole 2001: Tillid. En Bordum, Anders/Wenneberg, Søren Barlebo (eds.), Det handler om Tillid. Copenhague: Samfundslitteratur, 24-37.

Ury, W. L./Brett, J. M./Goldberg, S. B. 1988: Getting Disputes Resolved: Designing Systems to Cut the Costs of Conflict. San Fransisco: Jossey-Bass Publishers.

Vos, Henk de/Wielers, Rudi 2003: Calculativeness, trust and the reciprocity complex: is the market the domain of cynicism? En Nooteboom, Bart/Six, Fréderique (eds.), The Trust Process in Organizations. Cheltenham, UK: Edward Elgar, 75-105.

Weiss, S. E./Stripp W. 1998: Negotiating with foreign business persons. En Niemeier/ Campell/Diren (eds.), The cultural context of business communication. John Benjamins Publishing Company, 51-118.

Williamson, Oliver E. 1993: Calculativeness, Trust, and Economic Organization. En Law \& Economics XXXVI (1), 453-486.

Wu, Jenai/Laws, David 2003: Trust and Other-Anxiety in Negotiations: Dynamics Across Boundaries of Self and Culture. En Negotiation Journal, Oct. 2003, 329367.

Zartman, I. William/Berman, Maureen R. 1982: The Practical Negotiator. Yale University Press. 